OPEN ACCESS

Approved by:

Paula R. Pohlmann,

Georgetown University, United States

*Correspondence:

Frontiers Editorial Office

editorial.office@frontiersin.org

Specialty section:

This article was submitted to

Women's Cancer

a section of the journal

Frontiers in Oncology

Received: 30 March 2020

Accepted: 30 March 2020

Published: 07 April 2020

Citation:

Frontiers Editorial Office (2020)

Retraction: The role of microRNAs in the tumorigenesis of ovarian cancer.

Front. Oncol. 10:585

doi: 10.3389/fonc. 2020.00585

\section{Retraction: The role of microRNAs in the tumorigenesis of ovarian cancer}

\section{Frontiers Editorial Office*}

\section{A Retraction of the Review Article}

The role of microRNAs in the tumorigenesis of ovarian cancer

by Di Leva, G., and Croce, C. M. (2013). Front. Oncol. 3:153. doi: 10.3389/fonc.2013.00153

The journal retracts the June 13, 2013 article cited above.

Following publication, the authors contacted the Editorial Office to request that their article be corrected because of the inappropriate manner in which the article was written, which specifically involved improper reuse of text from previous articles. An investigation was conducted in accordance with our established procedures that confirmed the extensive and dispersed nature of the overlap; therefore, the article has been retracted.

This retraction was approved by the Chief Editors of Frontiers in Oncology and the Editor-inChief of Frontiers. The authors did not agree to this retraction.

Copyright (๑) 2020 Frontiers Editorial Office. This is an open-access article distributed under the terms of the Creative Commons Attribution License (CC BY). The use, distribution or reproduction in other forums is permitted, provided the original author(s) and the copyright owner(s) are credited and that the original publication in this journal is cited, in accordance with accepted academic practice. No use, distribution or reproduction is permitted which does not comply with these terms. 